Jurnal Ilmu-Ilmu Peternakan 26 (2): 49 - 59

ISSN : 0852-3681

E-ISSN : 2443-0765

CFakultas Peternakan UB, http://jiip.ub.ac.id/

\title{
Efektivitas pemberdayaan peternak broiler melalui pola kemitraan inti plasma oleh PT. Jaguar Farm di Kabupaten Malang
}

\author{
Jendro Adi Prabowo, Irdaf dan Siti Azizah \\ Fakultas Peternakan, Universitas Brawijaya, Malang \\ Jl. Veteran Malang 65145 Jawa Timur \\ nyut99@gmail.com
}

\begin{abstract}
This qualitative research was conducted in PT. Jaguar Farm from 18 May to 28 June 2016. Sample was purposively selected using snowball sampling method followed by in-depth interviews. Data was analysed using descriptive analysis. The results showed that Standard Operating Company of PT. Jaguar Farm was not too difficult and can be understood by all farmers. But the system seemed to be still one-sided contract which was determined only by the company, while farmers did not have a bargaining position to adjust the contract awarded. The patron-client system run by PT. Jaguar Farm was relatively new so that the clients who joined the company's business were mostly small farmers, in the sense that they still required assistance in the form of capital, extension and marketing. Another finding showed however that the client had a problem in the delay time of harvesting process. Therefore, the study concluded that PT. Jaguar Farm as the core in the patron-client business was able to show good enough performance, but there were some drawbacks that possibly could harm farmers.
\end{abstract}

Keywords: Partnership, contract farming, breeding farm, empowerment

\section{PENDAHULUAN}

Agribisnis unggas khususnya ayam ras pedaging (broiler) di Indonesia merupakan salah satu agribisnis yang berkembang paling cepat. Usaha yang dimulai dari usaha keluarga pada tahun 1950-an berkembang dengan cepat menjadi agribisnis modern yang ditandai dengan berkembangnya industri hulu dan hilir. Hasil Sensus Pertanian tahun 2013 menunjukkan bahwa jumlah rumah tangga yang bergerak dalam usaha peternakan sekitar 4,5 juta rumah tangga dari 21,4 juta usaha peternakan yang ada, dan 10 persennya merupakan usaha peternakan unggas.
Kabupaten Malang merupakan salah satu kabupaten yang tergolong memiliki tingkat aktivitas ekonomi yang cukup tinggi. Hal ini terlihat dari besarnya jumlah Produk Domestik Regional Bruto (PDRB) Kabupaten Malang yang menduduki peringkat 6 dari 33 kabupaten/kota di Provinsi Jawa Timur setelah Kota Surabaya, Kota Kediri, Kabupaten Sidoarjo, Kabupaten Kediri dan Kabupaten Pasuruan. Sektor ekonomi yang memberikan kontribusi paling tinggi selama kurun waktu lima tahun terakhir (2011-2015) adalah sektor agribisnis dan populasi ayam broiler di Kabupaten Malang mencapai 14,24\% (194.064.874 ekor). Sebagai 
salah satu alternatif sumber protein hewani, daging ayam broiler merupakan bahan pangan yang murah dan gampang diolah, sehingga menjadi pengganti kebutuhan protein dari daging sapi yang relatif mahal. Hal tersebut memicu berkembangnya usaha peternakan ayam broiler di masyarakat. Selain itu, adanya dukungan dari kerjasama kemitraan sistem inti plasma antara perusahaan swasta dan peternak.

Pada konteks pemberdayaan masyarakat keadaan ini memiliki dua arti. Pertama, didalam proses pemberdayaan ada pihak yang kuat untuk memberi kekuatan pada pihak yang lemah. Pada konsep ini dapat dikatakan efektif karena ada perusahaan (inti) berkenan menolong atau memberdayakan peternak kecil dengan memberi bantuan sarana dan prasarana. Namun pada sisi lain, poin kedua peternak kecil tidak memiliki posisi tawar atau hukum yang seimbang dalam menghadapi perjanjian sehingga peternak tetap lemah dibandingkan inti sehingga prinsip-prinsip pemberdayaan tidak berjalan seperti yang diharapkan. Hal ini berarti masyarakat akan terus tergantung pada inti, apabila inti bangkrut maka plasma juga menutup usahanya. Berdasarkan latar belakang tersebut penelitian ini bertujuan mengetahui peran efektivitas perusahaan PT. Jaguar Farm (inti) dalam pemberdayaan peternak lokal (plasma).

\section{MATERI DAN METODE}

Penelitian ini dilaksanakan pada PT. Jaguar Farm di Malang Jawa Timur pada tanggal 18 Mei sampai 28 Juni 2016. Metode penelitian menggunakan metode kualitatif, yakni mengamati orang dalam lingkungan hidupnya, berinteraksi dengan mereka, berusaha memahami bahasa dan tafsiran mereka tentang dunia sekitarnya (Sugiyono, 2015). Pada penelitian kualitatif, sampel sumber data dipilih menggunakan perspektif emic, artinya mementingkan pandangan informan, yakni bagaimana mereka memandang dan menafsirkan dunia dari pendiriannya. Teknik pengambilan data dengan melakukan wawancara mendalam kepada informan.

Data dianalisis secara deskriptif mengikuti konsep Susanti (2013) yang mengemukakan bahwa aktivitas dalam analisis data kualitatif dilakukan secara interaktif dan berlangsung secara terusmenerus pada setiap tahapan penelitian sehingga sampai tuntas dan datanya sampai jenuh. Aktivitas tersebut adalah data reduksi (data reduction), penyajian data (data display), dan conclusion drawing atau verification.

\section{HASIL DAN PEMBAHASAN}

\section{Gambaran lokasi penelitian}

Jumlah angka pengangguran dari tahun ke tahun terus mengalami peningkatan. Menurut Dinas Tenaga Kerja dan Transmigrasi Kabupaten Malang, pada tahun 2015 terdapat sekitar 31.000 orang yang masih menganggur. Banyaknya jumlah angka kemiskinan di Kabupaten Malang disebabkan keterbatasan lapangan kerja dan kualitas Sumber Daya Manusia (SDM) yang masih rendah. Pemerintah diharapkan berupaya mengatasi masalah tersebut, karena dilihat dari segi geografis Kabupaten Malang berpotensi untuk pengembangan usaha peternakan.

Pembangunan peternakan di Kabupaten Malang dilakukan dengan pendekatan kewilayahan atau kawasan pengembangan yang mengarah pada pembentukan klaster komoditas unggulan. Klaster tersebut diarahkan pada kawasan-kawasan sentra produksi peternakan di Kabupaten Malang, antara lain:

1. Kawasan sentra produksi sapi perah di Malang Barat (Kecama- 
tan Dau, Ngajum, Wonosari, Wagir, Pujon dan Ngantang), Malang Timur (Kecamatan Jabung, Tumpang, Poncokusumo dan Wajak), dan Malang Tengah (Kecamatan Gondanglegi dan Bantur)

2. Kawasan sentra produksi sapi potong di daerah Malang Selatan (Kecamatan Dampit, Sumbermanjing Wetan, Gedangan, Bantur, Donomulyo, Pagak dan Kalipare), Malang Tengah (Kecamatan Wajak, Turen, Sumberpucung dan Kromengan) dan Malang Timur (Kecamatan Lawang, Singosari, Pakis, Tumpang dan Poncokusumo)
3. Kawasan sentra produksi kambing di daerah Kecamatan Ampelgading, Tirtoyudo, Wajak, Kalipare, Pagak, Dampit dan Kromengan;

4. Kawasan sentra produksi ayam broiler dan petelur pada daerah Kecamatan Pakis, Tumpang, Wajak, Ngajum, Sumberpucung, Wagir dan Bululawang.

Sentra peternakan di kabupaten Malang memegang peran besar dalam peningkatan ekonomi daerah, khususnya peternakan ayam broiler yang kurun waktu 3 tahun terakhir selalu mengalami peningkatan populasi. Data peningkatan populasi peternakan di Kabupaten Malang dapat dilihat pada Tabel 1.

Tabel 1. Populasi komoditas ternak di Kabupaten Malang

\begin{tabular}{|c|c|c|c|c|c|c|}
\hline No & Jenis ternak & 2011 & 2012 & 2013 & 2014 & 2015 \\
\hline 1 & Sapi potong & 225.895 & 240.746 & 189.145 & 199.453 & 212.821 \\
\hline 2 & Sapi perah & 89.431 & 93.992 & 72.217 & 75.683 & 78.029 \\
\hline 3 & Kerbau & 2.421 & 2.445 & 1.394 & 1.226 & 1.127 \\
\hline 4 & Kambing & 194.269 & 203.932 & 225.374 & 235.121 & 240.823 \\
\hline 5 & Domba & 26.237 & 26.976 & 30.392 & 31.496 & 3.284 \\
\hline 6 & Babi & 6.102 & 6.318 & 12.028 & 12.241 & 12.826 \\
\hline 7 & Kuda & 692 & 685 & 614 & 626 & 836 \\
\hline 8 & Ayam buras & 1.807 .318 & 2.096.489 & 2.141 .663 & 2.201 .66 & 2.254 .982 \\
\hline 9 & Ayam petelur & 2.666 .662 & 2.733 .458 & 2.920 .857 & 3.005 .562 & 3.597 .860 \\
\hline 10 & Ayam broiler & 4.486.074 & 3.648 .864 & 4.135.418 & 17.557 .738 & 27.642.192 \\
\hline 11 & Itik & 166.171 & 169.491 & 226.149 & 400.472 & 468.481 \\
\hline 12 & Entok & 65.399 & 66.707 & 92.412 & 400.287 & 420.892 \\
\hline
\end{tabular}

Sumber: Dinas Peternakan Provinsi Jawa Timur 2015

Tabel 1 menunjukkan bahwa peningkatan populasi ayam broiler tahun 2014 meningkat drastis, bahkan paling tinggi dibandingkan dengan populasi ternak lainnya karena usaha ayam broiler lebih mudah dan biaya modal awal tidak sebesar komoditas ternak lain. Peningkatan budidaya broiler di Kabupaten Malang semakin tinggi, sehingga dapat menjadi landasan pemerintah untuk pengembangan usaha broiler di Kabupaten Malang dengan harapan mampu mengatasi masalah kemiskinan dan dapat membuka lapangan pekerjaan. Sejalan dengan itu, Soedarmanto (2003) menyatakan bahwa individu yang diberdayakan adalah orang miskin yang tidak memiliki daya untuk berjuang. Dengan demikian, intervensi orang luar (perusahaan swasta) untuk memberdayakan peternak masih sangat dibutuhkan.

\section{Profil PT. Jaguar Farm}

PT. Jaguar Farm adalah perusahaan yang bergerak dalam usaha 
kemitraan ayam broiler di wilayah Jawa Timur. Kantor pusatnya berada di Kota Malang dengan total plasma yang bergabung 134 plasma aktif. Perusahaan ini mulai beroperasi pada tanggal 19 Februari 2011. PT. Jaguar Farm memiliki dua cabang yaitu di Kota Malang dan Kota Jombang. Selanjutnya, pada Maret 2011 PT. Jaguar Farm bergabung dengan perusahaan "DK (Double K)" sebagai perusahaan induk penghasil sapronak. Kerjasama ini berlangsung selama kurang lebih 19 bulan dan pada tanggal 3 September 2012 bergabung dengan Ganesha yang berpusat di Semarang. Perusahaan tersebut merupakan anak perusahaan PT. Charoen Pokphand Indonesia sebagai induk penghasil sapronak. Alasan bekerjasama dengan PT. Ganesha tentu tidak lepas dengan kualitas sapronak yang lebih baik. Perusahaan ini masih tergolong baru beroperasi dan berkembang karena hanya sebagai penyedia jasa, belum sepenuhnya dapat memproduksi sapronak dan juga belum mempunyai pasar sendiri. PT. Jaguar Farm melakukan kerjasama dengan PT. Ganesha karena belum mampu memproduksi sapronak sendiri.

\section{Pemahaman program kemitraan}

Pada hasil penelitian, perusahaan dan peternak juga saling membutuhkan. Saling membutuhkan berarti perusahaan memerlukan hasil panen yang baik dan peternak plasma memerlukan bimbingan untuk memaksimalkan hasil. Saling menguntungkan berarti peternak memperoleh peningkatan pendapatan atau keuntungan disamping adanya kesinambungan usaha. Saling memperkuat artinya peternak plasma dan perusahaan inti sama-sama melaksanakan etika bisnis, sama-sama mempunyai persamaan hak dan saling membina sehingga memperkuat kesinambungan dalam bermitra.
Kemitraan usaha merupakan salah satu instrumen kerja sama yang mengacu kepada terciptanya suasana keseimbangan, keselarasan dan keterampilan yang didasari saling percaya antara perusahaan inti dan plasma (Martodireso dan Suryanto, 2007).

Peternak plasma yang mengikuti program kemitraan dengan PT. Jaguar Farm mayoritas adalah peternak berskala kecil. Para peternak memilih untuk mengikuti program kemitraan karena memiliki keterbatasan modal, pemasaran, dan kendala penguasaan teknologi.

\section{Ketepatan waktu dan sasaran pro- gram kemitraan}

Hasil penelitian menunjukkan bahwa saat ini program kemitraan sangat dibutuhkan oleh peternak kecil. Peternak tidak perlu dipusingkan dengan kendala modal untuk membuka usaha peternakan. Selain itu, kemampuan pemerintah juga belum maksimal dalam memberikan bantuan usaha. Usaha peternakan broiler sangat berkembang pesat karena adanya program kemitraan.

Peternak kecil masih sangat membutuhkan bantuan perusahaan berupa modal, arahan teknis dan pemasaran. Pemerintah juga diharapkan mampu berperan dalam mengawasi kegiatan kemitraan yang dilakukan perusahaan inti dengan baik sesuai Peraturan Pemerintah no 44 tahun 1997 pasal 23 tentang Kemitraan yang menjelaskan bahwa menteri teknis bertanggung jawab memantau dan mengevaluasi pembinaan pengembangan pelaksanaan usaha kemitraan sesuai tugasnya masing-masing. Selain itu, pemerintah juga masih belum melaksanakan pembinaan terlebih dahulu kepada peternak kecil, seperti yang tercantum dalam Pasal 22 Peraturan pemerintah nomor 94 tahun 1997 tentang Kemitraan yang menyebutkan bahwa lembaga pen- 
dukung berperan mempersiapkan dan menjembatani usaha kecil yang akan bermitra.

Menurut Imaduddin (2001), tantangan kemitraan yang lebih berat terjadi apabila ada perbedaan orientasi dan budaya kerja. Peternak seringkali kesulitan mengikuti budaya industrial yang dibawa oleh mitra kerjanya. Sebaliknya, perusahaan juga mengalami kesulitan untuk menerima kondisi dan sikap tradisional yang dibawa oleh peternak. Salah satu cara untuk mengatasi masalah ini adalah pemahaman atas kondisi masing-masing dan adanya kesempatan untuk berkomunikasi bagi semua pihak yang didorong oleh kepentingan dan keinginan untuk mencapai tujuan bersama. Pemecahan kendala teknis dapat diusahakan bersama dengan tenaga pendamping atau petugas TS. Seperti dalam masalah budidaya ayam broiler, vaksinasi dan sanitasi kandang berdasarkan pelatihan dan pengalaman tentu tidak mengalami masalah. Secara garis besar, perusahaan inti mempunyai tanggung jawab terhadap peternak kecil mitranya dalam memberikan bantuan dan pembinaan mulai dari sarana produksi, bimbingan teknis sampai dengan pemasaran hasil produksi. Sebagai contoh dalam hubungan kemitraan antara perusahaan inti dengan peternak plasma ini, perusahaan inti berupaya menyediakan bibit ayam (DOC), vaksin dan pakan selama berlangsungnya kegiatan pemeliharaan. Sedangkan pihak peternak plasma menyediakan lahan (area) dan kandang, pelaksanaan pemeliharaan secara intensif harus diupayakan mendapat pengawasan dan pembinaan teknis dari perusahaan inti.

\section{Implementasi program kemitraan}

Perusahaan memberikan penjelasan kontrak kepada peternak dua hari sebelum peternak setuju dengan apa yang ditawarkan oleh perusahaan. Peternak diberi kebebasan untuk menghitung keuntungannya sebelum terikat kontrak dengan perusahaan. Berikut adalah syarat kontrak yang ditawarkan oleh PT. Jaguar Farm kepada peternak plasma:

Ketentuan pihak satu (inti):

1. Mengirim sarana produksi ternak (sapronak) berupa DOC, pakan, obat, vaksin, kimia (OVK) kepada pihak dua (plasma) dengan hargaharga sesuai dengan kesepakatan kontrak yang ditandatangani

2. Berhak mengontrol (mengawasi dan menghitung) atas penggunaan sapronak yang dikirm kepada pihak dua (plasma)

3. Mengambil langkah-langkah yang diperlukan untuk mendukung kelancaran proses produksi pihak dua (plasma)

4. Melakukan panen hasil pemeliharaan ayam pihak dua (plasma) sesuai dengan target berat ayam yang disepakati dan harga sesuai harga kesepakatan (kontrak) yang ditandatangani

5. Membayar rekapitulasi hasil produksi peternakan (RHPP) pada pihak dua (plasma) setelah dilakukan perhitungan sesuai tanda bukti transaksi yang sah, tiga (tiga) hari kerja (tidak termasuk hari libur) dari panen terakhir jika semua prosedur telah diselesaikan

6. Berhak menahan agunan atau jaminan milik pihak dua (plasma), jika pihak dua (plasma) terbukti menjual OVK dan atau menjual ayam dan atau menjual pakan tanpa seijin pihak satu (inti), selanjutnya jaminan akan dikembalikan jika sudah ada penyelesaian

7. Berhak mengambil secara sepihak aset di kandang (tempat pakan, tempat minum, pemanas, alat semprot dan lain-lain) milik pihak 
dua (plasma) apabila pihak dua (plasma) terindikasi atau bahkan menjual OVK atau menjual ayam dan atau menjual pakan tanpa seijin pihak satu (inti). Penyitaan tersebut sebagai agunan sementara dan akan dikembalikan jika sudah ada penyelesaian

8. Berhak melaporkan kasus ke kepolisian jika pihak dua (plasma) menjual OVK dan atau menjual ayam dan atau menjual pakan tanpa seijin pihak satu (inti) sedangkan kasus tidak dapat diselesaikan secara kekeluargaan

Ketentuan pihak dua (plasma):

1. Melakukan proses budidaya ayam broiler dengan menggunakan sapronak pakan dan DOC yang dikirim oleh pihak satu (inti)

2. Melakukan pencatatan atas penggunaan sapronak pada lembar recording. Selisih antara jumlah barang secara fisik di kandang (stok opname) dengan catatan administrasi diartikan sebagai barang hilang dan menjadi tanggung jawab penuh

3. Ayam sesuai dengan delivery order (DO) yang dikeluarkan pihak satu (inti) secara sah. Pihak dua (plasma) wajib melakukan penimbangan panen dengan menggunakan alat timbangan dan metode penimbangan yang telah disepakati bersama. Pihak dua (plasma) dilarang menjual ayam tanpa DOC dari pihak satu (inti)

4. Berhak mendapat hadian (reward) senilai Rp. 250 atau ekor x populasi $\mathrm{x}$ jumlah periode, jika memenuhi ketentuan sebagai berikut:

a. Dalam 12 bulan (setahun) jumlah periode pemeliharaan minimal sebanyak enam kali panen (6 periode), khusus panen kecil $(<1 \mathrm{~kg})$ minimal sebanyak delapan kali panen (8 periode)

b. Dalam 12 bulan (setahun) IP kumulatif 300 (open house), IP kumulatif 350 (closed house), IP kumulatif 290 (panen kecil closed house)

c. Hadiah atau reward akan batal jika dalam 12 bulan (setahun) RHPP pernah minus dan atau pernah terindikasi atau terbukti menjual sapronak tanpa ijin

5. Rugi menanggung artinya RHPP minus ditanggung sepenuhnya oleh pihak dua (plasma) jika terbukti RHPP minus karena ada unsur pihak 2 (plasma) menjual ayam maupun sapronak, jika tidak terbukti RHPP minus tidak ditanggung pihak dua (plasma)

6. Pihak dua (plasma) bertanggung jawab secara hukum pidana atas kehilangan sapronak dengan alasan apapun termasuk menjual OVK dan atau menjuakl ayam dan atau menjual pakan tanpa seijin pihak satu (inti) yang dikategorikan pencurian dan siap diproses sesuai hukum pidana yang berlaku

7. Jika terindikasi atau bahkan terbukti menjual OVK dan atau menjual ayam dan atau menjual pakan tanpa seijin pihak satu (inti) maka akan merelakan aset di kandang (tempat pakan, tempat minum, pemanas, alat semprot dan lain-lain) untuk diambil sepihak oleh pihak satu (inti) sebagai agunan sementara dan berhak meminta dikembalikan jika urusan yang terjadi sudah selesai

8. Hal-hal yang sifatnya bencana alam (force majeure) yaitu kondisi merugikan yang tidak dapat dihindari akan dibuat berita acara dan akan menjadi pertimbangan bersama, sedangkan kondisi kebakaran dan kandang roboh bukan karena faktor alam adalah dikategorikan kelalaian 
sehingga ditanggung pihak 2 (plasma)

Isi kontrak perjanjian tersebut rata-rata tidak terlalu memberatkan peternak, kecuali ketentuan pihak dua pada poin 6 dan poin 7. Namun, peternak juga tidak mempunyai pilihan selain menerima karena pihak peternak tidak diberikan kebebasan untuk mengajukan persyaratan kontrak sendiri. Beberapa peternak juga masih belum memahami beberapa poin dari isi kontrak, karena bahasa hukum yang sulit dipahami oleh peternak. Sejalan dengan hal tersebut, Kuntowijoyo (2006) menjelaskan bahwa cara pandang masyarakat Jawa selalu bersikap pasrah pada nasib atau takdir. Sikap seperti ini biasanya juga disebut dengan sikap fatalistik, yaitu sikap pasrah atau menyerah pada takdir, bahwa didalam kehidupan manusia sudah mempunyai garis nasib atau takdir sendiri-sendiri. Kendati orang Jawa cenderung menghindari konflik karena sudah merasa dibantu.

Pelaksanaan sistem kemitraan ditentukan berdasarkan pembagian tugas yang telah disepakati dan dikelola lewat manajemen usaha bersama. Dengan kesepakatan demikian, keberhasilan usaha menjadi peran dan tanggung jawab setiap pelaku yang terlibat secara benar dan utuh didalam manajemen usaha bersama sesuai yang tercantum dalam Pasal 3 Keputusan Menteri Pertanian nomor 94 tahun 1997 tentang Pedoman Kemitraan Pertanian.

Seringnya TS datang ke peternak dapat mempengaruhi teknis budidaya mereka. Selain itu, materi yang diberikan juga penting diperhatikan agar sesuai dengan harapan peternak plasma. Peternak dalam kegiatan budidaya terkadang mengalami permasalahanpermasalahan seperti penyakit, penetapan standar dan lainnya. Peternak plasma bisa mengeluhkan permasalahan mereka kepada pihak inti melalui petu- gas TS atau datang langsung ke kantor pusat. Catatan petugas TS terhadap keluhan digunakan untuk mengetahui apakah peternak plasma selama ini sudah mendapat respon yang baik terhadap keluhan-keluhan yang disampaikan. Peran petugas TS dari kemitraan PT. Jaguar Farm masih belum maksimal, dimana para petugas TS kesulitan dalam membagi waktu untuk memberikan penyuluhan terhadap masing-masing peternak plasma karena keterbatasan jumlah petugas. Perusahaan inti menyediakan pendamping untuk membimbing peternak plasma agar hasilnya bisa maksimal. Namun, dalam prakteknya pendamping hanya sebagai pengontrol dan datang ke lokasi kandang seminggu sekali dan tidak melakukan pembinaan kepada peternak plasma, sehingga ketika ada masalah tidak bisa langsung dipecahkan. Hal ini kurang sesuai dengan isi dari Peraturan Pemerintah nomor 6 Tentang Pemberdayaan Peternak dimana peran perusahaan sebagai pendamping untuk memandu peternak dari awal hingga akhir.

Pada kontrak dijelaskan bahwa bobot badan digunakan sebagai acuan panen broiler sehingga waktu panen tidak bisa ditentukan dengan lamanya waktu pemeliharaan. Waktu panen yang terlalu lama menjadi masalah serius bagi peternak plasma. Hal tersebut dapat menguras waktu, tenaga dan penambahan biaya. Peternak harus menambah stok pakan lagi sampai waktu panen tiba. Mayoritas kendala yang dialami peternak plasma yaitu lamanya waktu panen. Pihak perusahaan inti beralasan bahwa keterlambatan panen disebabkan permintaan pasar yang sepi. Penundaan masa panen akan merugikan peternak, karena tidak ada perhitungannya. Padahal satu hari terlambat panen dapat menghabiskan uang untuk menanggung pakan yang harganya cukup besar, dan belum lagi biaya yang di- 
keluarkan peternak plasma untuk anak kandang. Pihak perusahaan menjelaskan bahwa pasar yang bekerja sama dengan PT. Jaguar Farm adalah pemborong (wholesale) bukan Rumah pemotongan Ayam (RPA) karena harga di RPA lebih rendah yaitu Rp. 16.000 per kg bobot hidup, sedangkan untuk harga pemborong sebesar Rp. $18.000 \mathrm{~kg}$ per bobot hidup. Menurut Dinas Peternakan dan Kesehatan Hewan Kabupaten Malang, harga jual di RPA dan bakul berbeda tergantung dari segmen pasarnya. Jika RPA kebanyakan masuk pada pasar becek atau pasar tradisional dan segmen pasar dari bakul atau pemborong masuk pada super market, hotel dan kapal pesiar sehingga harga jual daging ayam lebih tinggi. Upaya untuk mengurangi beban yang dialami peternak sudah dilakukan oleh perusahaan inti yang memberikan kebebasan kepada peternak untuk melakukan pencampuran pakan sendiri ketika ayam sudah mulai memasuki fase finisher atau setara dengan ayam berumur 26 hari ke atas untuk mengantisipasi keterlambatan panen, sehingga tidak menghabiskan konsentrat terlalu banyak karena harga pakan konsentrat yang mahal. Peternak diberi arahan untuk mencampur konsentrat dengan jagung dengan proporsi 3:1. Namun, hal tersebut juga memberatkan pihak peternak plasma karena perusahaan juga tidak menyediakan bahan campuran pakan (jagung) untuk peternak plasma, sehingga peternak mencari sendiri bahan campurannya. Selain itu, harga jagung juga mahal dan kualitasnya juga belum tentu baik.

\section{Perubahan peternak setelah bermitra}

Pada hasil penelitian diketahui bahwa peran perusahaan inti dalam melakukan pembinaan terhadap peternak plasma cukup berhasil. Penguasaan teknologi yang dimiliki peternak setelah bermitra dapat meningkat. Hal tersebut sesuai dengan UU RI nomor 16 tahun 2006 tentang Sistem Penyuluhan Pertanian yang menyebutkan bahwa penyuluhan pertanian adalah suatu proses pembelajaran bagi pelaku utama (pelaku kegiatan pertanian) serta pelaku usaha agar mereka mau dan mampu menolong dan mengorganisasikan dirinya dalam mengakses informasi pasar, teknologi, permodalan, dan sumberdaya lainnya, sebagai upaya untuk meningkatkan produktivitas, efisiensi usaha, pendapatan, dan kesejahteraannya, serta meningkatkan kesadaran dalam pelestarian fungsi lingkungan hidup. Sejalan dengan hal tersebut, Kusnadi (2011) menjelaskan bahwa tujuan penyuluhan yaitu meningkatkan taraf hidup dan meningkatkan kesejahteraan peternak yang diarahkan pada terwujudnya perbaikan teknis berternak (better farming), perbaikan usaha (better business), dan perbaikan kehidupan peternak dan masyarakatnya (better living). Peternak plasma yang bermitra sebagian besar memang peternak kecil. Sedangkan peternak yang sudah berpengalaman dan memiliki modal namun masih mengikuti program kemitraan ini biasanya hanya memandang dari segi bisnis, dimana mereka sudah memiliki modal sendiri dan pengalaman selama berternak.

Penguasaan teknologi oleh peternak plasma mampu meningkatkan pendapatan, sehingga dalam hal ini peran perusahaan inti dalam upaya memberdayakan peternak plasma cukup berhasil. Pendapatan yang semakin meningkat dapat meningkatkan taraf hidupnya. Sumodiningrat (2007) menyatakan bahwa pemberdayaan masyarakat berarti meningkatkan kemampuan masyarakat. Upaya pemberdayaan masyarakat dapat dilihat dari sisi: Pertama, menciptakan suasana yang memungkinkan masyarakat berkembang. Kedua, meningkatkan kemampuan masyarakat dalam mem- 
bangun melalui berbagai bantuan dana, pelatihan, pembangunan sarana dan prasarana baik fisik maupun sosial, serta pengembangan kelembagaan di daerah. Ketiga, melindungi atau memihak yang lemah untuk mencegah persaingan yang tidak seimbang dan menciptakan kemitraan yang saling menguntungkan. Secara lebih rinci Soedarmanto (2003) menekankan bahwa hakikat pemberdayaan adalah bagaimana membuat masyarakat mampu membangun dirinya dan memperbaiki kehidupannya sendiri. Istilah mampu disini mengandung makna: berdaya, paham, termotivasi, memiliki kesempatan, melihat dan memanfaatkan peluang, berenergi, mampu bekerjasama, mengetahui berbagai alternatif, mampu mengambil keputusan, berani mengambil risiko, mampu mencari dan menangkap informasi, serta mampu bertindak sesuai inisiatif.

Selama ini tingkat kemandirian peternak plasma masih belum terbentuk. Peternak plasma masih sangat bergantung pada perusahaan inti khususnya terkait modal dan pemasaran. Meskipun peternak plasma mempunyai pandangan kedepan untuk melakukan usaha mandiri, akan tetapi salama ini masih belum berani mengambil resiko tersebut. Suyono (2002) menjelaskan bahwa secara umum usaha kecil memiliki karakteristik sebagai usaha yang tergolong ekonomi lemah, baik dari aspek pengetahuan, keterampilan, teknologi yang digunakan, permodalan, pemasaran dan kerja sama yang masih rendah. Kelompok usaha ini sulit bersaing dengan perusahaan besar. Sebenarnya ini menjadi tugas pemerintah dalam upaya memberikan bantuan kepada peternak-peternak yang terlatih, dalam arti peternak plasma yang sudah mempunyai ilmu dan penguasaan teknologi setelah mengikuti program kemitraan dengan perusahaan swasta. Deshinta (2006) menyatakan bahwa pemerintah di dalam kerjasama kemitraan berperan dalam meningkatkan kemampuan manajerial kelompok ternak, dengan arah pembinaan untuk memantapkan budaya usaha berencana, menjalin hubungan kelembagaan untuk memperkuat koperasi, memantapkan hubungan kelembagaan antar peternak atau kelompok peternak untuk menjamin skala ekonomi produksi dan mampu bekerjasama dengan pihak lain.

Tujuan utama pemberdayaan peternak adalah kemandirian, dimana peternak mampu mengambil keputusan dengan pilihan terbaiknya sehingga mampu meraih peluang. Sumodiningrat (2007) mengartikan bahwa kemandirian adalah wirasawasta, yang berarti sifatsifat keberanian, keutamaan dan keteladanan dalam mengambil resiko yang bersumber pada kemampuan sendiri. Hasil penelitian menunjukkan bahwa peternak plasma yang bermitra dengan PT. Jaguar Farm tidak memiliki pilihan dalam melakukan kegiatan kemitraan, dimana peternak plasma hanya pasrah terhadap inti karena keterbatasan modal dan kendala pasar. Selain itu, beberapa peternak yang tidak mau lepas dengan kemitraan PT. Jaguar Farm Malang karena peternak beralasan sudah percaya pada perusahaan inti, mulai dari awal hingga akhir panen dan juga kejelasan pembayaran. Peran pemerintah sangat dibutuhkan bagi peternak-peternak yang sudah mengusai teknologi dalam pembudidayaan ayam broiler. Menurut peternak, mereka perlu bermitra dengan perusahaan inti karena belum mampu menanggung beban resiko atau kerugian tingginya modal dan teknologi. Hasyim (2005) yang menyatakan bahwa ketergantungan peternak terhadap perusahaan inti karena tingginya penggunaan modal, teknologi yang digunakan, pengelolaan usaha dan resiko kegagalan kemitraan. Pemerintah diharapkan mampu menggerakkan koperasi untuk 
mengatasi permasalahan modal dan dapat menjamin pasar supaya peternak mandiri tidak mengalami masalah dengan pemasaran. Secara lebih rinci Suyono (2002) menekankan bahwa konsep pemberdayaan berkembang dari realitas individu atau masyarakat yang tidak berdaya atau pihak yang lemah (powerless). Ketidakberdayaan memiliki kelemahan dalam aspek: pengetahuan, pengalaman, sikap, keterampilan, modal usaha, jaringan (networking), semangat, kerja keras, ketekunan dan aspek lainnya. Kelemahan dalam berbagai aspek tadi mengakibatkan ketergantungan, ketidakberdayaan dan kemiskinan.

Upaya-upaya pemberdayaan masyarakat seharusnya mampu berperan meningkatkan kualitas sumber daya manusia (SDM) terutama dalam membentuk dan merubah perilaku masyarakat untuk mencapai taraf hidup yang lebih berkualitas. Pemberdayaan masyarakat tidak lain adalah memberikan motivasi dan dorongan kepada masyarakat agar mampu mengubah cara pandang atau pola pikir mayarakat untuk berani bertindak memperbaiki kualitas hidupnya. Pada hasil penelitian, dalam upaya pemberdayaan terhadap peternak plasma, perusahaan inti diharapkan mampu mengubah pandangan peternak supaya bisa berkembang. Sebelumnya peternak selalu bergantung pada perusahaan inti dan tidak berani mengambil resiko untuk mencoba usaha mandiri. Hal tersebut dikarenakan peternak plasma masih membutuhkan bantuan terhadap perusahaan inti terkait kendala modal, arahan dan pemasaran. Peternak sebenarnya mempunyai keinginan untuk melakukan usaha mandiri, namun faktanya sampai saat ini peternak masih belum berani mengambil resiko tersebut. Peternak yang bergabung dengan PT. Jaguar Farm juga tidak hanya peternak kecil, peternak yang sudah memiliki memiliki modal juga belum berani membuka usaha mandiri. Sumodiningrat (2007) menjelaskan bahwa pembangunan yang berbasis pemberdayaan masyarakat (communty based development) sebagai wujud partisipasi masyarakat dalam konsep pembangunan berkelanjutan (suistainable development) meletakkan prioritas kegiatan pembangunan pada proses penguatan kapasitas, peningkatan kualitas sumber daya manusia dan pengembangan kelembagaan masyarakat yang bertujuan mengembangkan pola pikir positif, daya kritis, dan kontrol sosial masyarakat. Tujuan lain yang diharapkan dari pemberdayaan masyarakat adalah menumbuhkan kemandirian masyarakat dalam mengelola potensi ekonomi lokal bagi peningkatan taraf kehidupan masyarakat.

\section{KESIMPULAN}

PT. Jaguar Farm adalah perusahaan yang bergerak dalam bidang ayam broiler. Perusahaan ini beroperasi selama 4 tahun dengan 134 peternak plasma yang tersebar di Kabupaten Malang. Selama beroperasi perusahaan inti telah banyak membantu peternak kecil, namun masih belum dapat memberdayakan peternak plasma menjadi peternak mandiri seperti yang tertera dalam Peraturan Pemerintah nomor 44 tahun 1997 tentang Kemitraan.

Efektivitas program PT. Jaguar Farm dalam manajemen perusahaan guna memberdayakan peternak plasmanya dapat ditinjau sebagai berikut:

1. Peternak menganggap bahwa perusahaan inti sangat berperan dalam kemitraan untuk membantu kendala yang dialami peternak berkaitan dengan modal, penguasaan teknologi dan pemasaran. 
2. Program kemitraan PT. Jaguar Farm masih tergolong perusahaan yang baru berkembang sehingga peternak plasma yang ikut tergabung dengan perusahaan merupakan peternak kecil, dalam arti masih memerlukan bantuan berupa modal, penyuluhan dan penyedia pasar.

3. Penyediaan sapronak, manajemen budidaya, harga kontrak dan pemasaran tidak menjadi masalah. Akan tetapi sistem kontrak yang masih bersifat memihak pada perusahaan tidak sesuai dengan asas kebebasan melakukan kontrak. Kendala waktu panen juga menjadi masalah serius untuk peternak plasma.

4. Penguasaan teknologi yang didapat peternak plasma setelah bermitra dapat membantu mereka dalam membudidayakan ayam broiler dengan baik. Akan tetapi perusahaan belum bisa memberdayakan peternak untuk bisa mandiri. Sebaliknya, perusahaan memberikan dampak ketergantungan kepada peternak plasma.

\section{DAFTAR PUSTAKA}

Deshinta, M. 2006. Peranan kemitraan terhadap peningkatan pendapatan peternak ayam broiler (Kasus kemitraan : PT. Sierad Produce dengan peternak di Kabupaten Sukabumi. Bogor : Fakultas Peternakan IPB.

Hasyim. $2005 . \quad$ Pengembangan kemitraan agribisnis: konsep, teori dan realita dalam ekonomi biaya transaksi. Pusat penerbitan lembaga penelitian Universitas Lampung. Lampung.

Imaduddin, R. 2001. Analisis kemitraan pola perusahaan inti-rakyat usaha peternakan ayam ras pedaging (Kasus PT. Ciomas Adisatwa Sukabumi). Fakultas Peternakan, Institut Pertanian Bogor.

Keputusan Menteri Pertanian Nomor 44 tahun 1997 tentang pedoman kemitraan pertanian.

Kuntowijoyo. 2006. Budaya dan masyarakat. Tiara wacana. Yogyakarta.

Kusnadi. 2011. Analisis kemitraan dan efisiensi ekonomi usaha ternak ayam broiler di Kecamatan Singaprana, Kabupaten Tasikmalaya, Jawa Barat. Jurusan ilmuilmu sosial ekonomi pertanian, Fakultas Pertanian, Institut Pertanian Bogor.

Martodireso dan Suryanto. 2007. Agribisnis kemitraan usaha bersama. Kanisius.Yogyakarta.

Peraturan Pemerintah Nomor 44 Tahun 1997 tentang kemitraan.

Soedarmanto. 2003. Penyuluhan komunikasi pertanian. UB Press. Malang

Sugiyono. 2015. Memahami penelitian kualitatif. Alfabeta. Bandung.

Sumodiningrat, G. 2007. Pemberdayaan sosial. Kompas. Jakarta.

Susanti, E. 2013. Penelitian kualitatif. Eds Bagong Suyanto dan Sutinah. Metode penelitian sosial. Kencana. Jakarta.

Suyono, H. 2002. Pemberdayaan masyarakat di era global. Alfabeta. Bandung. 